\title{
THE EFFECTS OF DIFFERENT NITROGEN DOSES AND IRRIGATION LEVELS ON YIELD, NUTRITIVE VALUE, FERMENTATION AND GAS PRODUCTION OF CORN SILAGE
}

\author{
Mahmut KAPLAN ${ }^{*}$, Ozkan BARAN ${ }^{1}$, Ali UNLUKARA ${ }^{2}$, Hasan KALE ${ }^{1}$, Mustafa ARSLAN ${ }^{1}$, Kanber \\ $K A R A^{3}$, Selma Buyukkilic BEYZI ${ }^{4}$, Yusuf KONCA ${ }^{4}$, Abdullah $U L A S^{5}$ \\ ${ }^{1}$ University of Erciyes, Faculty of Agriculture, Department of Field Crops, Kayseri, TURKEY \\ ${ }^{2}$ University of Erciyes, Faculty of Agriculture, Department of Biosystem Engineering, Kayseri, TURKEY \\ ${ }^{3}$ University of Erciyes, Faculty of Veterinary Medicine, Department of Animal Nutrition and Nutritional \\ Diseases, Kayseri, TURKEY \\ ${ }^{4}$ University of Erciyes, Faculty of Agriculture, Department of Animal Science, Kayseri, TURKEY \\ ${ }^{5}$ University of Erciyes, Faculty of Agriculture, Department of Soil Science and Plant Nutrition, Kayseri, \\ TURKEY \\ Corresponding author: mahmutkaplan5@hotmail.com
}

Received: 25.01.2016

\begin{abstract}
The study was conducted to investigate the effects of different irrigation levels and nitrogen doses on yield, yield parameters, silage characteristics, digestibility, gas and methane production of corn silage. Three different irrigation levels $(50 \%, 75 \%$ and $100 \%$ of depleted water) and 3 different nitrogen doses $(100,200$ and $300 \mathrm{~kg}$ $h^{-1}$ N) were applied to corn silage. Experiments were implemented in split-split plots design with three replications during the growing seasons of 2013-2014. Plants were harvested at milk-dough stage and yield and morphologic characteristics were determined. Then, harvested plants were silaged and chemical characteristics were investigated. Irrigation level $x$ nitrogen dose interaction was not found to be significant. Increasing nitrogen doses increased plant height, plant diameter, green herbage yield, crude protein, metabolic energy, gas production and organic matter digestibility and decreased $\mathrm{pH}$ levels, ADF and NDF ratios. Increased irrigation levels positively affected green herbage yield, plant height, plant diameter and increased ADF and NDF ratios. Gas production, metabolic energy and organic matter digestibility decreased with increasing irrigation levels. Increasing irrigation levels improved corn yields, but reduced the quality. On the other hand, increasing nitrogen doses had positive contributions both to yield and quality characteristics.
\end{abstract}

Key words: Chemical composition, corn silage, gas production irrigation, nitrogen fertilization

\section{INTRODUCTION}

Silage is commonly used in animal feeding of the countries with developed livestock industry since the silage has a high nutritive value and moisture content. It is also easy to store and preserve the silage, it has longlasting life, it is easily digested due to fermentation, the high-quality feed can be preserved for long durations, it allows the rations with high dry matter and moisture content (Tukel and Hatipoglu, 1997), the protein supplied by silage is cheaper than the protein supplied by fabricated mixed feeds and the silage has high provitamin A content (Tumer, 2001).

Maize can yield quite high green herbage and easily be harvested. It is consumed by livestock with a good appetite (Neylon and Kung, 2003; Kaplan, 2005), suitable for silage and has quite high nutritive values. Thus, maize is the most significant silage crop both worldwide and in Turkey
(McDonald et al., 1991; Meeske et al., 1993). Irrigation and fertilizations are the greatest cost items in crop culture and they are also among the most significant factors effecting the yield and quality in pasture and forage crops (Islam et al., 2012; Khelil et al., 2013). Water and nitrogen are the critical issue in maize culture, especially for yield and quality of maize. Therefore, these two parameters should be optimized in maize culture. Current global warming and climate change (World Water Assessment Program, 2009) restrict the water resources and thus enforce the growers to perform such optimizations. Increased water and nitrogen treatments not only increase the production costs, but also result in serious environmental pollution over the agricultural fields (Ferrer et al., 1997) and negative influenceson soil structure (Khelil et al., 2013). Nitrogenous fertilization and synergic effect of water improve nutrient uptake and yields (Kim et al., 2008). 
Recently in vitro gas production technique with chemical composition have been widely used to evaluate the potential nutritive value of previously uninvestigated forages since in vitro gas production technique is quick, cheap, less time consuming (Kamalak and Canbolat, 2010). In addition, in vitro gas production technique was used to screen the feedstuffs in terms of their methane reduction potential. Methane production during rumen fermentation is one of important contributors to global warming (Lassey, 2007).

There are many studies regarding the water usage and nitrogen application in silage corn (Istanbulluoglu et al., 2002; Kiziloglu et al., 2009). But in the present studies we have principally focused on the yield, morphological characteristics and chemical composition parameters There are insufficient knowledge and information about optimum water and nitrogen doses and their effects on yield and silage quality, volatile fatty acids, gas and methane production of maize. Thus, the objectives of the present study were set as assess the effects of irrigation $\mathrm{x}$ nitrogen interaction (i) on yield and yield parameters, (ii) silage quality, (iii) metabolic energy (ME), organic matter digestibility (OMD), gas and methane production-like digestibility parameters.

\section{MATERIALS AND METHODS}

\section{Field Experiments}

Experiments were conducted in Kayseri Province of Turkey $\left(38^{\circ} 43^{\prime} \mathrm{N} ; 3^{\circ} 29^{\prime} \mathrm{E}\right)$ during the growing seasons of 2013-2014 for two years. Simon hybrid maize cultivar was used as the plant material of the study. Seeds were sown over $6 \times 4.2 \mathrm{~m}$ plots with $70 \mathrm{~cm}$ row spacing and $16 \mathrm{~cm}$ onrow plant spacing (Kusvuran et al., 2015). Experiments were conducted in split-split plots experimental design with three replications. Three different irrigation levels based on depleted water from field capacity $(50,75$ and $100 \%)$ were placed over main plots and 3 nitrogen doses $(\mathrm{N} 1=100$, $\mathrm{N} 2=200$ and $\mathrm{N} 3=300 \mathrm{~kg} \mathrm{ha}^{-1} \mathrm{~N}$ ) were placed over sub-plots. Soil moisture content was measured with a neutron probe and the amount of irrigation water to be applied was determined and applied through a drip irrigation method. Based on soil analysis, half of nitrogen was applied at sowing and the other half was applied when the plants had a height of $50 \mathrm{~cm}$. Besides nitrogen fertilization, $100 \mathrm{~kg} \mathrm{ha}^{-}$ ${ }^{1} \mathrm{P}_{2} \mathrm{O}_{5}$ was also applied at sowing (Gul et al., 2008). Hoeing and chemical weed control was practiced throughout the growing season. Morphologic observations were measured at milk-dough stage of the plants and then plants were harvested. Side effects were omitted and resultant yields were calculated.

\section{Soil and climate characteristics of research site}

Seeds were sown on $23^{\text {rd }}$ of April in the first year and $28^{\text {th }}$ of April in the second year. Experimental years generally had higher temperatures to long-term averages. Precipitations were lower than the long-term averages in the first year and higher than the long-term averages in the second year. Relative humidity levels of the experimental years were generally lower than the long-term averages. Not specified in Table 1, but unexpected short-term low temperatures were also experienced in experimental years.

Table 1. Precipitation, temperature and relative humidity data of the experimental site

\begin{tabular}{lccccccccc}
\hline & \multicolumn{3}{c}{ Temperature $\left({ }^{\circ} \mathbf{C}\right)$} & \multicolumn{3}{c}{ Precipitation $(\mathbf{m m})$} & \multicolumn{3}{c}{ Relative Humidity (\%) } \\
\cline { 2 - 10 } Months & $\mathbf{2 0 1 3}$ & $\mathbf{2 0 1 4}$ & $\begin{array}{c}\text { Long } \\
\text { Term* }\end{array}$ & $\mathbf{2 0 1 3}$ & $\mathbf{2 0 1 4}$ & $\begin{array}{c}\text { Long } \\
\text { Term* }\end{array}$ & $\mathbf{2 0 1 3}$ & $\mathbf{2 0 1 4}$ & $\begin{array}{c}\text { Long } \\
\text { Term* }\end{array}$ \\
\hline April & 12.1 & 14.1 & 10.7 & 43.6 & 2.9 & 54.8 & 56.2 & 44.3 & 62.6 \\
May & 18.1 & 16.7 & 15.1 & 31.3 & 39.7 & 52.0 & 44.7 & 50.4 & 60.8 \\
June & 21.1 & 19.7 & 19.1 & 12.6 & 52.9 & 39.1 & 38.7 & 46.8 & 55.3 \\
July & 22.5 & 25.2 & 22.6 & 3.4 & 0.0 & 10.3 & 36.9 & 33.7 & 49.5 \\
August & 22.5 & 25.1 & 22.0 & 0.8 & 47.4 & 5.3 & 36.0 & 37.4 & 49.8 \\
September & 17.0 & 18.8 & 17.1 & 10.3 & 85.4 & 13.3 & 44.1 & 54.2 & 54.4 \\
October & 9.2 & 11.7 & 11.5 & 52.5 & 54.4 & 30.5 & 58.9 & 68.1 & 64.0 \\
Mean & 17.5 & 18.7 & 16.8 & - & - & - & 45.0 & 47.8 & 56.6 \\
Total & - & - & - & 154.5 & 282.7 & 205.3 & - & - & - \\
\hline
\end{tabular}

Experimental soils at 0-30 and 30-60 cm were classified as sandy-loam in both years. Soils had low lime and salt content, were rich in potassium and phosphorus, poor in organic matter and were slightly alkaline.

\section{Preparation and analysis of silage samples}

The maize grown under three different irrigation levels and nitrogen doses were harvested at milk-dough stage. The plants were chopped in $2.5-3 \mathrm{~cm}$ pieces, filled and sealed in $2 \mathrm{~kg}$ deflated vacuum bags. Then the samples were preserved in dark $\left(24 \pm 2^{\circ} \mathrm{C}\right)$ for 60 days. Sample bags were opened and $30 \mathrm{~g}$ sample was mixed with $270 \mathrm{ml}$ water to measure the $\mathrm{pH}$ of samples. Again $250 \mathrm{~g}$ fresh silage sample was dried in an oven at $70{ }^{\circ} \mathrm{C}$ for 48 hours to find dry matter ratio. Dried samples were then ground in a mill with $1 \mathrm{~mm}$ sieve and made ready for chemical analyses. Dry matter, crude protein and crude ash analyses were performed in accordance with the methods specified in AOAC (1990). NDF and ADF analyses were carried out in accordance with the methods specified in Van Soest and Wine (1967) and Van Soest (1963), respectively by using an ANKOM 200 Fiber Analyzer (ANKOM Technology Corp. Fairport, NY, USA). Acetic, propionic and butyric acid contents were determined by using a gas 
chromatography device (Shimadzu GC-2010 Kyoto, Japan with column characteristics of: $30 \mathrm{~m} \times 0.25 \mathrm{~mm} \times 0.25 \mu \mathrm{m}$, Restek, temperature range of $45-230^{\circ} \mathrm{C}$ ) and lactic acid analysis was performed by using spectrophotometric method (Barker and Summerson, 1941).

Table 2. Physical and chemical characteristics of soils of the experimental site

\begin{tabular}{|c|c|c|c|c|}
\hline \multirow[b]{2}{*}{ Properties } & \multicolumn{2}{|c|}{2013} & \multicolumn{2}{|c|}{2014} \\
\hline & $0-30 \mathrm{~cm}$ & $30-60 \mathrm{~cm}$ & $0-30 \mathrm{~cm}$ & $30-60 \mathrm{~cm}$ \\
\hline Clay $(\%)$ & 13.10 & 8.94 & 12.58 & 9.18 \\
\hline Silt $(\%)$ & 4.16 & 10.40 & 5.11 & 9.55 \\
\hline Sand $(\%)$ & 82.74 & 80.66 & 82.31 & 81.27 \\
\hline Class & Sandy-Loam & Sandy-Loam & Sandy-Loam & Sandy-Loam \\
\hline $\mathrm{pH}$ & 7.94 & 7.75 & 7.48 & 7.60 \\
\hline Organic Matter (\%) & 1.05 & 1.27 & 1.09 & 1.14 \\
\hline $\mathrm{CaCO}_{3}(\%)$ & 0.28 & 0.27 & 0.24 & 0.29 \\
\hline $\mathrm{K}_{2} \mathrm{O}\left(\mathrm{kg} \mathrm{ha}^{-1}\right)$ & 1092.20 & 755.14 & 1184.20 & 842.34 \\
\hline $\mathrm{P}_{2} \mathrm{O}_{5}\left(\mathrm{~kg} \mathrm{ha}^{-1}\right)$ & 89.63 & 11.56 & 110.41 & 12.58 \\
\hline $\mathrm{EC}\left(\mathrm{mmhos} \mathrm{cm}^{-1}\right)$ & 0.96 & 0.23 & 0.83 & 0.27 \\
\hline
\end{tabular}

\section{In vitro Hohenheim gas production technique}

Rumen fluid, which required for in vitro gas production technique, was obtained from a Simmental steer beef (at 12 months of age and in $600 \mathrm{~kg}$ live weight). Animal care procedures for the experiment were conducted under a research protocol approved by the Local Ethics Committee for Animal Experiments of Erciyes University, KayseriTurkey.

Rumen fluid was collected into a glass bottle (Isolab, Germany). The bottle was transported to the laboratory in a sealed thermos container at $39 \pm 1^{\circ} \mathrm{C}$ and filtered through four layers of cheesecloth under $\mathrm{CO}_{2}$ gas. In vitro gas production was analyzed in twenty seven different silage samples. The samples were incubated in rumen fluid and buffer mixture in $100 \mathrm{ml}$ glass syringes (Model Fortuna, HaberleLabortechnik, Germany) following the procedures of Menke and Steingass, (1988). About 200 $\pm 10 \mathrm{mg}$ dry samples were weighed in triplicate into glass syringes. The syringes were prewarmed at $39^{\circ} \mathrm{C}$ in a thermostatically controlled cabinet (Lovibond, Austria), before $10 \mathrm{ml}$ of rumen fluid and $20 \mathrm{ml}$ of prewarmed buffer mixture were dispensed anaerobically in each syringe using an automatic bottletop dispenser (Isolab, Germany). The syringes were closed using one position polypropylene clamps and incubated at $39 \pm 0.5^{\circ} \mathrm{C}$ for $24 \mathrm{~h}$. In addition, three blank syringes (no template; rumen fluid + buffer mixture) were used to calculate the total gas production.

\section{Determination of total gas and methane productions}

After $24 \mathrm{~h}$ of incubation, the total gas volume was recorded from the calibrated scale on the syringe. After measuring the total gas volume, the tubing of the plastic syringe outlet was inserted into the inlet of the methane analyzer (Sensor, Europe GmbH, Erkrath, Germany) and the piston was pushed to insert the accumulated gas into the analyzer. The methane as percent of the gas was displayed on a PC (Goel et al., 2008).

\section{Determination of metabolic energy $(M E)$ and} organic matter digestibility (OMD)

The ME and OMD levels of silage samples were calculated using the equations of Menke et al.(1979) and Blümmel et al. (1997) as follows:

$M E(M J / k g D M)=2.20+0.136 \times G P+0.057 \times C P$

$O M D(g / k g D M)=14.88+0.889 \times G P+0.45 \times C P+$ $0.0651 \times A$

$G P=24$ het gas production $(\mathrm{ml} / 200 \mathrm{mg})$.

$C P=$ Crude protein

$A=$ Ash content

\section{Statistical analysis}

The two-year experimental data were subjected to variance analysis with SAS (SAS Inst. 1999) software in accordance with split-split plots experimental design. LSD test was used to assess the significance of differences in treatment means.

\section{RESULTS}

Morphological characteristics of corn silage grown under different irrigation levels and nitrogen doses are provided in Table 3. Irrigation levels and nitrogen doses had highly significant effects on green herbage yield, plant height, cob and leaf ratios $(\mathrm{P}<0.01)$, irrigation levels had significant effects on plant diameter $(\mathrm{P}<0.05)$, and nitrogen doses had significant effects on plant diameter $(\mathrm{P}<0.01)$. The effects of irrigation $\mathrm{x}$ nitrogen interaction were not significant $(\mathrm{P}>0.05)$. Significant increases were observed in green herbage yields with increasing irrigation levels and nitrogen doses and the highest yield $75.2 \mathrm{t} \mathrm{ha}^{-1}$ was obtained from $100 \%$ water levels and $75.0 \mathrm{t} \mathrm{ha}^{-1}$ was obtained from N3 nitrogen doses. Plant height had also similar responds to water and nitrogen treatments and increased with increasing water levels and nitrogen doses plant height of maize samples varied between 184.13 and $207.56 \mathrm{~cm}$ in irrigation levels and $188.28-203.41 \mathrm{~cm}$ in nitrogen doses. 
Plant diameter increased with increasing nitrogen doses, but the difference between N2 (21.32 mm) and N3 (22.39 $\mathrm{mm})$ treatments was not significant. Plant diameters also increased with irrigation levels, but the difference was observed only at $100 \%$ irrigation level $(21.90 \mathrm{~mm})$. While irrigation levels and nitrogen doses increased cob ratios, a decrease was observed in leaf ratio. Cob ratio of the samples varied between 51.64-54.35\% in irrigation levels and $51.98-54.59 \%$ in nitrogen doses. Leaf ratio of the samples varied between $20.60-17.05 \%$ in irrigation levels and $20.53-16.54 \%$ in nitrogen doses. Stem ratio increased with nitrogen doses, but the difference was observed in N3 treatment. The greatest stem ratio $(28.88 \%)$ was obtained from N3 treatment.

Table 3. The effects of irrigation levels and nitrogen doses on morphological characteristics and herbage yield of corn

\begin{tabular}{|c|c|c|c|c|c|c|c|c|c|}
\hline \multirow{2}{*}{$\begin{array}{l}\text { Irrigation } \\
\text { Level }\end{array}$} & \multicolumn{4}{|c|}{ Green Herbage Yield $\left(\mathrm{t} \mathrm{ha}^{-1}\right)$} & \multirow{3}{*}{$\begin{array}{l}\text { Irrigation } \\
\text { Level }\end{array}$} & \multicolumn{4}{|c|}{ Plant Height (cm) } \\
\hline & \multicolumn{3}{|c|}{ Fertilizer Doses } & \multirow[t]{2}{*}{ Means } & & \multicolumn{3}{|c|}{ Fertilizer Doses } & Means \\
\hline & N1 & $\mathrm{N} 2$ & N3 & & & N1 & $\mathrm{N} 2$ & N3 & \\
\hline 50 & 48.9 & 63.6 & 70.5 & $61.0 \mathrm{~b}$ & 50 & 174.72 & 185.95 & 191.72 & $184.13 \mathrm{c}$ \\
\hline 75 & 54.9 & 68.0 & 73.6 & $65.5 \mathrm{~b}$ & 75 & 189.56 & 204.33 & 206.89 & $200.26 \mathrm{~b}$ \\
\hline 100 & 64.4 & 80.3 & 80.9 & $75.2 \mathrm{a}$ & 100 & 200.56 & 210.50 & 211.61 & $207.56 \mathrm{a}$ \\
\hline Means & $56.1 \mathrm{c}$ & $70.6 \mathrm{~b}$ & $75.0 \mathrm{a}$ & & Means & $188.28 \mathrm{c}$ & $200.26 \mathrm{~b}$ & $203.41 \mathrm{a}$ & \\
\hline
\end{tabular}

\begin{tabular}{|c|c|c|c|c|c|c|c|c|c|}
\hline \multirow{2}{*}{$\begin{array}{l}\text { Irrigation } \\
\text { Level }\end{array}$} & \multicolumn{4}{|c|}{ Plant Diameter (mm) } & \multirow{3}{*}{$\begin{array}{l}\text { Irrigation } \\
\text { Level }\end{array}$} & \multicolumn{4}{|c|}{ Cob Ratio (\% DM) } \\
\hline & \multicolumn{3}{|c|}{ Fertilizer Doses } & \multirow[t]{2}{*}{ Means } & & \multicolumn{3}{|c|}{ Fertilizer Doses } & Means \\
\hline & N1 & $\mathrm{N} 2$ & $\mathrm{~N} 3$ & & & N1 & $\mathrm{N} 2$ & $\mathrm{~N} 3$ & \\
\hline 50 & 18.86 & 20.39 & 21.94 & $20.40 \mathrm{~b}$ & 50 & 50.29 & 51.28 & 53.37 & $51.64 \mathrm{~b}$ \\
\hline 75 & 18.60 & 20.81 & 22.20 & $20.54 \mathrm{~b}$ & 75 & 52.17 & 53.77 & 55.08 & $53.67 \mathrm{a}$ \\
\hline 100 & 19.92 & 22.74 & 23.03 & $21.90 \mathrm{a}$ & 100 & 53.47 & 54.27 & 55.32 & $54.35 \mathrm{a}$ \\
\hline Means & $19.13 \mathrm{~b}$ & $21.32 \mathrm{a}$ & $22.39 \mathrm{a}$ & & Means & $51.98 \mathrm{c}$ & $53.11 \mathrm{~b}$ & $54.59 \mathrm{a}$ & \\
\hline
\end{tabular}

\begin{tabular}{|c|c|c|c|c|c|c|c|c|c|}
\hline \multirow{2}{*}{$\begin{array}{l}\text { Irrigation } \\
\text { Level }\end{array}$} & \multicolumn{4}{|c|}{ Leaf Ratio (\% DM) } & \multirow{2}{*}{$\begin{array}{l}\text { Irrigation } \\
\text { Level }\end{array}$} & \multicolumn{4}{|c|}{ Stem Ratio (\% DM) } \\
\hline & \multicolumn{3}{|c|}{ Fertilizer Doses } & \multirow[t]{2}{*}{ Means } & & \multicolumn{3}{|c|}{ Fertilizer Doses } & Means \\
\hline & N1 & N2 & N3 & & & N1 & $\mathrm{N} 2$ & $\mathrm{~N} 3$ & \\
\hline 50 & 23.24 & 21.05 & 17.51 & $20.60 \mathrm{a}$ & 50 & 26.47 & 27.68 & 29.11 & 27.75 \\
\hline 75 & 19.95 & 18.18 & 16.56 & $18.23 \mathrm{~b}$ & 75 & 27.87 & 28.05 & 28.38 & 28.10 \\
\hline 100 & 18.38 & 17.23 & 15.54 & $17.05 \mathrm{c}$ & 100 & 28.15 & 28.50 & 29.15 & 28.60 \\
\hline Means & $20.53 \mathrm{a}$ & $18.82 \mathrm{~b}$ & $16.54 \mathrm{c}$ & & Means & $27.50 \mathrm{~b}$ & $28.08 \mathrm{~b}$ & $28.88 \mathrm{a}$ & \\
\hline
\end{tabular}

$\mathrm{N} 1: 100, \mathrm{~N} 2: 200$ and $\mathrm{N} 3: 300 \mathrm{~kg} \mathrm{ha}^{-1} \mathrm{~N}$

Nitrogen treatments had highly significant effects on $\mathrm{pH}(\mathrm{P}<0.05), \mathrm{ADF}(\mathrm{P}<0.01), \mathrm{NDF}(\mathrm{P}<0.01)$, dry matter $(\mathrm{P}<0.01)$, crude protein $(\mathrm{P}<0.01)$ and crude ash $(\mathrm{P}<0.01)$. Irrigation levels had also highly significant effects on ADF, NDF and dry matter $(\mathrm{P}<0.01)$, significant effects on crude ash $(\mathrm{P}<0.05)$, but insignificant effects on $\mathrm{pH}$ and crude protein. The effects of irrigation $\mathrm{x}$ nitrogen interaction on chemical composition were not significant $(\mathrm{P}>0.05)$. Increasing nitrogen doses reduced dry matter contents. Dry matter contents of silage samples varied between 28.80 $32.30 \%$. The $\mathrm{pH}$ of silage samples decreased with increasing nitrogen doses. With regard to $\mathrm{pH}$ values, $\mathrm{N} 1$ and $\mathrm{N} 2$ treatments were placed in the same group, but the decrease accelerated in $\mathrm{N} 3$ treatment. The $\mathrm{pH}$ values of the study varied $3.92-4.02$ which were within the ideal value for corn silage. ADF and NDF values increased with increasing irrigation levels, but decreased with increasing nitrogen doses. The lowest $\mathrm{ADF}$ and NDF values were respectively observed as $22.15 \%$ and $46.08 \%$ and the greatest values were respectively observed as $28.55 \%$ and $49.85 \%$. Crude protein contents of silage samples increased with increasing nitrogen doses and varied between 6.41$7.70 \%$. Crude ash content of silage samples increased with increasing levels and decreased with increasing nitrogen doses. Crude ash content of silage samples increased with increasing irrigation levels and decreased with increasing nitrogen doses.

Mean values for acid composition (lactic, acetic, propionic and butyric acid) of maize silage are provided in Table 5. The effects of nitrogen doses, irrigation levels, nitrogen $\mathrm{x}$ irrigation interaction on lactic, acetic, propionic and butyric acid contents were not found to be significant. Lactic acid contents of silage samples varied between 4.394.62\% DM, acetic acid contents varied between 1.22$1.25 \%$ DM, butyric acid contents varied between 0.000 $0.008 \% \mathrm{DM}$ and propionic acid contents varied between 0.003-0.008\% DM (Table 5).

The effects of irrigation levels and nitrogen doses on gas production, metabolic energy and organic matter digestibility were found to be highly significant $(\mathrm{P}<0.01)$ (Table 6). The effects of irrigation and nitrogen treatments on methane production were not found to be significant. Similarly, the effects of irrigation $\mathrm{x}$ nitrogen interaction on gas and methane production were not found to be significant $(\mathrm{P}>0.05)$. Increasing nitrogen doses increased gas production, metabolic energy and organic matter digestibility. Gas production values of silage samples varied between 40.51-45.78 mL, metabolic energy varied between $8.10-8.82 \mathrm{MJ} / \mathrm{kg} \mathrm{DM}$ and organic matter digestibility varied between $54.82-59.58 \%$. 
Table 4. The effects of irrigation levels and nitrogen doses on chemical composition of corn silage

\begin{tabular}{|c|c|c|c|c|c|c|c|c|c|}
\hline \multirow{2}{*}{$\begin{array}{l}\text { Irrigation } \\
\text { Level }\end{array}$} & \multicolumn{4}{|c|}{ Dry Matter (\%) } & \multirow{2}{*}{$\begin{array}{l}\text { Irrigation } \\
\text { Level }\end{array}$} & \multicolumn{4}{|c|}{ pH } \\
\hline & \multicolumn{3}{|c|}{ Fertilizer Doses } & Means & & \multicolumn{3}{|c|}{ Fertilizer Doses } & Means \\
\hline & N1 & $\mathrm{N} 2$ & N3 & & & $\mathrm{N} 1$ & $\mathrm{~N} 2$ & N3 & \\
\hline 50 & 33.47 & 31.11 & 29.27 & $31.28 \mathrm{a}$ & 50 & 4.02 & 4.00 & 4.00 & 4.01 \\
\hline 75 & 32.29 & 30.63 & 28.59 & $30.50 \mathrm{~b}$ & 75 & 4.02 & 3.99 & 3.86 & 3.97 \\
\hline 100 & 31.13 & 29.74 & 28.54 & $29.81 \mathrm{c}$ & 100 & 4.02 & 3.99 & 3.91 & 3.96 \\
\hline Means & $32.30 \mathrm{a}$ & $30.50 \mathrm{~b}$ & $28.80 \mathrm{c}$ & & Means & $4.02 \mathrm{a}$ & $3.99 \mathrm{a}$ & $3.92 \mathrm{~b}$ & \\
\hline \multirow{3}{*}{$\begin{array}{l}\text { Irrigation } \\
\text { Level }\end{array}$} & \multicolumn{4}{|c|}{ ADF (\%) } & Irrigation & \multicolumn{4}{|c|}{ NDF (\%) } \\
\hline & \multicolumn{3}{|c|}{ Fertilizer Doses } & Means & Level & \multicolumn{3}{|c|}{ Fertilizer Doses } & Means \\
\hline & N1 & $\mathrm{N} 2$ & N3 & & & $\mathrm{N} 1$ & $\mathrm{~N} 2$ & N3 & \\
\hline 50 & 26.89 & 23.89 & 22.10 & $24.29 \mathrm{~b}$ & 50 & 48.99 & 47.13 & 45.69 & $47.27 \mathrm{~b}$ \\
\hline 75 & 29.00 & 26.21 & 21.85 & $25.68 \mathrm{ab}$ & 75 & 49.29 & 47.56 & 45.43 & $47.43 \mathrm{ab}$ \\
\hline 100 & 29.75 & 27.28 & 22.51 & $26.51 \mathrm{a}$ & 100 & 51.27 & 47.79 & 47.14 & $48.73 \mathrm{a}$ \\
\hline Means & $28.55 \mathrm{a}$ & $25.79 \mathrm{~b}$ & $22.15 \mathrm{c}$ & & Means & $49.85 \mathrm{a}$ & $47.49 \mathrm{~b}$ & $46.08 \mathrm{c}$ & \\
\hline \multirow{3}{*}{$\begin{array}{l}\text { Irrigation } \\
\text { Level }\end{array}$} & \multicolumn{4}{|c|}{ Crude Protein (\%) } & Irrigation & \multicolumn{4}{|c|}{ Crude Ash (\%) } \\
\hline & \multicolumn{3}{|c|}{ Fertilizer Doses } & Means & Level & \multicolumn{3}{|c|}{ Fertilizer Doses } & Means \\
\hline & N1 & $\mathrm{N} 2$ & N3 & & & $\mathrm{N} 1$ & $\mathrm{~N} 2$ & N3 & \\
\hline 50 & 6.64 & 7.36 & 7.73 & 7.24 & 50 & 6.66 & 5.94 & 5.69 & $6.10 \mathrm{~b}$ \\
\hline 75 & 6.31 & 7.11 & 7.69 & 7.04 & 75 & 6.66 & 6.43 & 5.81 & $6.30 \mathrm{ab}$ \\
\hline 100 & 6.27 & 7.03 & 7.67 & 6.99 & 100 & 7.12 & 6.54 & 6.23 & $6.63 \mathrm{a}$ \\
\hline Means & $6.41 \mathrm{c}$ & $7.17 \mathrm{~b}$ & $7.70 \mathrm{a}$ & & Means & $6.81 \mathrm{a}$ & $6.30 \mathrm{~b}$ & $5.91 \mathrm{c}$ & \\
\hline
\end{tabular}

Table 5. The effects of irrigation levels and nitrogen doses on silage acids of corn silage

\begin{tabular}{|c|c|c|c|c|c|c|c|c|c|}
\hline \multirow{2}{*}{$\begin{array}{l}\text { Irrigation } \\
\text { Level } \\
\end{array}$} & \multicolumn{4}{|c|}{ Lactic Acid (\% DM) } & \multirow{2}{*}{$\begin{array}{l}\text { Irrigation } \\
\text { Level }\end{array}$} & \multicolumn{4}{|c|}{ Acetic Acid (\% DM) } \\
\hline & \multicolumn{3}{|c|}{ Fertilizer Doses } & \multirow[t]{2}{*}{ Means } & & \multicolumn{3}{|c|}{ Fertilizer Doses } & \multirow[t]{2}{*}{ Means } \\
\hline & N1 & $\mathrm{N} 2$ & N3 & & & N1 & $\mathrm{N} 2$ & N3 & \\
\hline 50 & 4.39 & 4.40 & 4.60 & 4.46 & 50 & 1.24 & 1.25 & 1.24 & 1.24 \\
\hline 75 & 4.51 & 4.53 & 4.62 & 4.55 & 75 & 1.22 & 1.22 & 1.23 & 1.22 \\
\hline 100 & 4.51 & 4.55 & 4.62 & 4.56 & 100 & 1.24 & 1.24 & 1.25 & 1.24 \\
\hline Means & 4.47 & 4.49 & 4.62 & & Means & 1.23 & 1.24 & 1.24 & \\
\hline \multirow{2}{*}{$\begin{array}{l}\text { Irrigation } \\
\text { Level } \\
\end{array}$} & \multicolumn{4}{|c|}{ Butyric Acid (\% DM) } & Irrigation & \multicolumn{4}{|c|}{ Propionic Acid (\% DM) } \\
\hline & \multicolumn{3}{|c|}{ Fertilizer Doses } & Means & Level & \multicolumn{3}{|c|}{ Fertilizer Doses } & Means \\
\hline & N1 & $\mathrm{N} 2$ & N3 & & & N1 & $\mathrm{N} 2$ & N3 & \\
\hline 50 & 0.000 & 0.000 & 0.000 & 0.000 & 50 & 0.005 & 0.003 & 0.003 & 0.004 \\
\hline 75 & 0.000 & 0.000 & 0.000 & 0.000 & 75 & 0.008 & 0.008 & 0.003 & 0.007 \\
\hline 100 & 0.008 & 0.000 & 0.000 & 0.003 & 100 & 0.007 & 0.007 & 0.008 & 0.007 \\
\hline Means & 0.003 & 0.000 & 0.000 & & Means & 0.007 & 0.006 & 0.005 & \\
\hline
\end{tabular}


Table 6. The effects of irrigation levels and nitrogen doses on gas production, methane, metabolic energy and organic matter digestibility of corn silage

\begin{tabular}{|c|c|c|c|c|c|c|c|c|c|}
\hline \multirow{2}{*}{$\begin{array}{l}\text { Irrigation } \\
\text { Level }\end{array}$} & \multicolumn{4}{|c|}{ Gas Production (mL) } & \multirow{3}{*}{$\begin{array}{l}\text { Irrigation } \\
\text { Level }\end{array}$} & \multicolumn{4}{|c|}{$\mathrm{CH}_{4}(\mathrm{~mL})$} \\
\hline & \multicolumn{3}{|c|}{ Fertilizer Doses } & \multirow[t]{2}{*}{ Means } & & \multicolumn{3}{|c|}{ Fertilizer Doses } & Means \\
\hline & N1 & $\mathrm{N} 2$ & N3 & & & N1 & $\mathrm{N} 2$ & N3 & \\
\hline 50 & 39.13 & 43.01 & 44.49 & $42.21 \mathrm{~b}$ & 50 & 13.55 & 13.38 & 12.75 & 13.23 \\
\hline 75 & 38.14 & 40.93 & 44.31 & $41.13 \mathrm{~b}$ & 75 & 13.68 & 12.93 & 13.97 & 13.53 \\
\hline 100 & 44.25 & 46.52 & 48.55 & $46.44 \mathrm{a}$ & 100 & 12.88 & 13.60 & 14.07 & 13.52 \\
\hline Means & $40.51 \mathrm{c}$ & $43.49 \mathrm{~b}$ & $45.78 \mathrm{a}$ & & Means & 13.37 & 13.31 & 13.59 & \\
\hline
\end{tabular}

\begin{tabular}{|c|c|c|c|c|}
\hline \multirow{3}{*}{$\begin{array}{l}\text { Irrigation } \\
\text { Level }\end{array}$} & \multicolumn{4}{|c|}{ Metabolic Energy (MJ/kg DM) } \\
\hline & \multicolumn{3}{|c|}{ Fertilizer Doses } & Means \\
\hline & N1 & $\mathrm{N} 2$ & $\mathrm{~N} 3$ & \\
\hline 50 & 7.96 & 8.45 & 8.65 & $8.35 \mathrm{~b}$ \\
\hline 75 & 7.77 & 8.2 & 8.60 & $8.19 \mathrm{~b}$ \\
\hline 100 & 8.58 & 8.97 & 9.21 & $8.92 \mathrm{a}$ \\
\hline & & $8.54 \mathrm{~b}$ & $8.82 \mathrm{a}$ & \\
\hline
\end{tabular}

\begin{tabular}{|c|c|c|c|c|}
\hline \multirow{2}{*}{$\begin{array}{l}\text { Irrigation } \\
\text { Level }\end{array}$} & \multicolumn{4}{|c|}{ Organic Matter Digestibility (\%) } \\
\hline & \multicolumn{3}{|c|}{ Fertilizer Doses } & Means \\
\hline & $\mathrm{N} 1$ & $\mathrm{~N} 2$ & N3 & \\
\hline 50 & 53.92 & 57.06 & 58.48 & $56.49 \mathrm{~b}$ \\
\hline 75 & 52.67 & 55.54 & 58.11 & $55.44 \mathrm{~b}$ \\
\hline 100 & 57.88 & 60.58 & 62.16 & $60.21 \mathrm{a}$ \\
\hline Means & $54.82 \mathrm{c}$ & $57.73 \mathrm{~b}$ & $59.58 \mathrm{a}$ & \\
\hline
\end{tabular}

$\mathrm{N} 1: 100, \mathrm{~N} 2: 200$ and $\mathrm{N} 3: 300 \mathrm{~kg} \mathrm{ha}^{-1} \mathrm{~N}$

\section{DISCUSSION}

This study was conducted to investigate the effects of different irrigation levels and nitrogen doses on yield, morphologic traits, chemical composition, and digestibility characteristics of corn silage. Experiments were conducted during the summer growing season for two years. Unexpected short-term low temperatures during the spring and autumn of the experimental years had significant impacts on yield, morphologic characteristics and chemical composition. Such low temperatures resulted in a constriction in leaves, thickening in cell walls (increasing $\mathrm{ADF}$ and NDF ratios), a recess in growth and development (Galdamez-Cabrera et al., 2002; Mahajan and Tuteja 2005) and various other relevant changes in plant cells. All these variations might have resulted in differences between the years.

Increasing irrigation levels and nitrogen doses increased plant height, plant diameter, stem and cob ratios and ultimately increased green herbage yields. Leaf ratio was reduced by irrigation levels and nitrogen doses. Nitrogenous fertilization speeds up the growth and development in meristem cells located at the bottom sections of internodes, thus increases plant heights of maize (Sezer and Yanbeyi, 1997). It was indicated in previous studies that nitrogenous fertilization generally increased plant heights (Islam et al., 2010), but such increases were not continuous and insufficient nitrogen levels resulted in decrease in plant heights, biomass and kernel yield (Subedi and $\mathrm{Ma}, 2005)$. Among the plant nutrients like nitrogen, phosphorus and potassium, Ping et al., (1993) indicated nitrogen as the most significant nutrient specifying plant height. Otegui et al. (1995) and Istanbulluoglu et al. (2002) reported decreasing plant heights and Kiziloglu et al. (2009) reported reduced green herbage yield with water deficits. Nitrogen deficiency negatively affects vegetative structure in maize and result in poor plant development (Akar et al., 2014). When the plants are not able to find the required nitrogen, they are forced to bloom and growing season is shortened. In this case, top tassel and cob tassel development is reduced and quite low kernel is formed at the tip of cobs (Kirtok, 1998). When the plants are able to find sufficient nitrogen, they keep normal growth and speed up kernel development in cobs (Akar et al., 2014). In this case, cob ratio increases and leaf and shoot ratio decreases in plants. Yilmaz (2005) reported decreasing leaf ratios with increasing nitrogen doses. Other researchers also indicated decreasing leaf area index and thus leaf ratios (Kang et al., 1986) and increasing green herbage yield (Kumar et al., 2001) with increasing nitrogen doses in maize. Water stress effects leaf and stem elongation (Song et al., 2010) and limits root development (Sharp and Davies 1979). Water stress is commonly resulted from reduced carbohydrate and photosynthesis rates and accelerated stomal closures (Kaiser, 1987; Foyer et al., 1998). Plant stomas close under stress conditions and consequently carbohydrate, proline, glycine and protein metabolites accumulate in leaves (Pelleschi et al., 1997). Such results support the our current findings.

Increasing irrigation levels increased $\mathrm{ADF}$ and NDF ratios and increasing nitrogen doses reduced $\mathrm{ADF}$ and NDF ratios. Yosef et al. (2009) reported increased NDF ratio and in vitro digestibility in sorghum with increasing water levels and Islam et al. (2012) reported the similar findings in maize. Increasing ADF and NDF ratios decrease crude protein and WSC ratios (Hargreaves et al. 2009). Increased nitrogen doses increase $\mathrm{CP}$ and in vitro digestibility (Cox and Charney, 2005). In this study, protein ratios decreased with increasing water levels, but the changes were not found to be significant. Increasing $\mathrm{ADF}$ and NDF ratios make the digestion difficult and ultimately result in decreased crude protein, gas production, metabolic energy and digestible organic matter content (Kamalak et al., 2011). Increasing nitrogen doses and irrigation levels may also increase cob ratios and thus kernel ratios and energy values (Islam et al., 2012).

Nitrogen has a critical role in protein and enzyme synthesis in plants. Entire metabolic processes are controlled by enzymes. Moreover, nitrogen constitutes a 
component in chlorophyll synthesis which is the primary molecule absorbing the energy needed in photosynthesis (Islam et al., 2010). In maize plants, available water and nitrogen increase photosynthesis rates especially in kernelfill period (Uribelarrea et al., 2004), then sucrose and other sugars are regularly transported into ears like nitrogen (Spielbauer et al., 2006; Swank et al., 1982). Continuous post-flowering nitrogen transport from vegetative organs to ears and leaflets may improve the kernel nitrogen content (Christensen et al., 1981; Swank et al., 1982).

Ball et al. (1996) indicated that dry matter and protein contents of cultivars might vary not only based on plant genetics but also based on leaf, spike and stem ratios, ripening period, temperature and fertilization. Increased cob ratio with increasing nitrogen doses and irrigation levels of the our study contributed to crude protein ratios. Water stress may reduce nutrient transport in plants and thus terminate dry matter accumulation (Kruse et al., 2008; Setter and Parra 2010). In our study, increasing nitrogen doses and irrigation levels reduced the dry matter contents. Besides, current dry matter ratios (28.54-33.47\%) were quite close to expected ratios (about 30\%) (Keady, 2005).

Low $\mathrm{pH}$ levels indicate the existence of acidified atmosphere with fermentation of soluble sugars (Islam et al., 2012). Low $\mathrm{pH}$ ranges in silage samples of the our study (3.86-4.02) are the indicator of lactic acid accumulation providing the preservation of silage quality and leading the microbial activities (McDonald et al., 1991). The decrease in $\mathrm{pH}$ levels with increasing irrigation levels and nitrogen doses increased lactic acid contents. Water stress has direct impact on cob development and kernel-fill (Andrade, 2002). The dissolved carbohydrates with increasing water levels increase lactic acid production and increased lactic acid then decrease pH levels (Bates 2009). Reduced kernel ratio also decreases energy levels (Mould et al., 1983) and reduces silage quality (Cox et al., 1993).

Lopez et al. (2010) classified the anti-methanogenic potential of feeds based on methane ratio of the gas released through fermentation as low (>\%11 and $\leq \% 14)$, medium (\%>6 and <\%11) and high (>\%0 and <\%6). According to this classification, current finding under different irrigation levels and nitrogen doses indicated the anti-methanogenic potential of maize silage as low (12.88-14.07 $\left.\mathrm{mL} \mathrm{CH}_{4}\right)$.

\section{CONCLUSION}

Our results revealed that increasing irrigation levels increased plant height and diameter but relatively reduced the quality of corn silage. Increased nitrogen doses increased plant height, diameter, green herbage yield, cob ratio and crude protein ratio, but reduced ADF and NDF ratios. Increasing nitrogen doses also increased metabolic energy and organic matter digestibility, but did not have significant effects on methane production. Nitrogen doses had positive impacts on silage fermentations, slightly increased lactic acid content and reduced $\mathrm{pH}$ levels. Irrigation levels $\mathrm{x}$ nitrogen doses interaction was not found to be significant, but the effects of years were significant. Ultimately, the effects of different irrigation levels and nitrogen doses on yield, yield parameters, chemical composition, gas and methane production, organic matter digestibility and metabolic energy were elucidated. Although we recommend applying 100 irrigation levels and N3 nitrogen dose, performing similar studies in different climatic and soil conditions will yield better results.

\section{ACKNOWLEDGEMENTS}

This study was supported by the Erciyes University Research Fund (grand No: FYL-2013-4616).

\section{LITERATURE CITED}

Akar, T., M. Kaplan, N. Sagir, A. Gelebur. 2014. Effects of different liquid-manure treatments on yield and quality parameters of second-crop silage corn under reduced tillage conditions. Romanian Agricultural Research. 31: 1-11.

Andrade, F.H., L. Encharte, R. Rizzalli, A.D. Maggiiora, M. Casanovas. 2002. Kernel Predtion in Maize under Nitrogen or Water Stress. Crop Sci. 42: 1173-1179.

AOAC, 1990. Official Methods of Analysis. 15th ed. Association of Official Analytical Chemists, Washington, DC.US.

Ball, D.M., C.S. Hoveland, G.D. Lacefield. 1996. Forage Quality. In. Southern Forages (2nd edition). 124-132. Potash \& Phosphate Institute and Foundation for Agronomic Research, Norcross, GA.

Barker, S.B., W.H. Summerson. 1941. The colorimetric determination of lactic acid in biological material. J. Biol. Chem. 138: 535-554.

Bates, G. 2009. Corn Silage. Agricultural Extension Service. The University of Tennessee. 1-8. http.//utbfc.utk.edu/Content\%20Folders/Forages/Hay\%20an d\%20Silage/Publications /sp434d.pdf

Blümmel, M., Makkar, H.P.S., Chisanga, G., Mtimuni, J., Becker, K. 1997. The prediction of dry matter intake of temperate and tropical roughages from in vitro digestibility/gas-production data, and the dry matter intake and in vitro digestibility of African roughages in relation to ruminant liveweight gain. Anim. Feed Sci. Tech. 69: 131-141.

Christensen, L.E., F.E. Below, R.H. Hageman. 1981. The effects of ear removal on senescence and metabolism of maize. Plant Physiol. 68: 1180-1185.

Cox, W.J., D.J.R. Charney. 2005. Row spacing, plant density, and nitrogen effects on corn silage. Agron. J. 93: 597-602.

Cox, W.J., S. Kalonge, D.J.R. W.S. CherneyReid. 1993. Growth, yield and quality of forage maize under different nitrogen management practices. Agron. J. 85: 843-347.

Ferrer, F., J.M. Villar, C.O. Stockle, P. Villar, M. Aran. 1997. Impacto del nitrógeno presente en el agua de riego en la zona regable del Canal d'Urgell (Nitrogen impact in irrigation water in the irrigated area of the Urgell's Channel). XV Congreso de Riegos y Drenajes, Lleida. 241-248.

Foyer, C.H., M.H. Valadier, A. Migge, T.W. Becker. 1998. Draught-induced effects on nitrate reductase activity and mRNA and on the coordination of nitrogen and carbon metabolism in maize leaves. Plant Physiol. 117: 283-292.

Galdamez-Cabrera, N.W., K.P. Coffey, W.K. Coblentz, J.E. Turner, D.A. Scarbrough, Z.B. Johnson. 2002. Effect of nitrogen fertilization on effective ruminal disappearance of dry matter, fiber and selected macro-minerals from common bermudagrass harvested on two different dates. Arkansas Animal Science Department Report Series. 499: 41-44.

Goel, G., H.P.S. Makkar, K. Becker. 2008. Effect of Sesbania sesban and Carduus pycnocephalus leaves and Fenugreek (Trigonella foenum-graecum L.) seeds and their extract on partitioning of nutrients from roughage-and concentratebased feeds to methane. Anim. Feed Sci. Tech. 147: 72-89. 
Gul, I., M. Yildirim, C. Akinci, I. Doran, H. Kilic. 2008. Response of Silage Maize (Zea mays L.) to Nitrogen Fertilizer after Different Crops in a Semi Arid Environment. Turk. J. Agric. For. 32: 513-520.

Hargreaves, A., J. Hill, J.D. Leaver. 2009. Effect of stage of growth on the chemical composition and nutritive value and ensilability of whole-crop barley. Anim. Feed Sci. Technol. 152: 50-61.

Islam, M.R., S.C. Garcia, A. Horadagoda. 2012. Effects of irrigation and rates and timing of nitrogen fertilizer on dry matter yield, proportions of plant fractions of maize and nutritive value and in vitro gas production characteristics of whole crop maize silage. Anim. Feed Sci. Tech. 172: 125135.

Islam, M.R., S.M.E. Rahman, M. Md. Rahman, D.H. Oh, C.S. Ra. 2010. The effects of biogas slurry on the production and quality of maize fodder. Turk. J. Agric. For. 34: 91-99.

Istanbulluoglu, A., I. Kocaman, F. Konukcu. 2002. Water useproduction relationship of maize under Tekirdag conditions in Turkey. Pak. J. Biol. Sci. 5: 287-291.

Kaiser, W.M. 1987. Effect of water deficit on photosynthetic capacity. Physiol. Plant. 71: 142-149.

Kamalak, A., A.I. Atalay, C.O. Ozkan, E. Kaya, A. Tatliyer. 2011 Determination of potential nutritive value of Trigonella kotschi fenzl hay harvested at three different maturity stages. Kafkas Univ. Vet. Fak. Derg. 17: 635-640.

Kamalak, A., Canbolat, O. 2010. Determination of nutritive value of wild narrow-leaved clover (Trifolium angustifolium) hay harvested at three maturity stages using chemical composition and in vitro gas production. Trop. Grassland, 44: 128-133.

Kang, J.H., H.J. Lee, B.H. Park. 1986. Effect of nitrogen level and plant population on agronomic characteristics and yield of silage maize. Soil and Fertilizers. 52: 95.

Kaplan, M. 2005. Effects of different intra and inter row spacing on yield and yield components of second crop silage maize (Zea mays L.) under Kahramanmaras conditions. Univercity of Kahramanmaras Sutcu Imam Enstitute of Natural and Applied Science Department of Field Crops. MSc Thesis.

Keady, T.W.J. 2005. Ensiled maize and whole crop; wheat forages for beef and dairy cattle. Effects on animal performance. Silage production and utilization. In. Park, R.S., Stronge, M.D. (Eds.), Proc. XIV International Silage Conference. Wageningen Academic Publishers, 65-82.

Khelil, M.N., S. Rejeb, B. Henchi, J.P. Destain. 2013. Effects of irrigation water quality and nitrogen rate on the recovery of $15 \mathrm{~N}$ fertilizer by sorghum in field study. Communications in Soil Science and Plant Analysis. 44: 2647-2655.

Kim, K., D.E. Clay, C.G. Carlson, S.A. Clay, T. Trooien. 2008 Do synergistic relationships between nitrogen and water influence the ability of corn to use nitrogen derived from fertilizer and soil? Agron. J. 100: 551-556.

Kirtok, Y. 1998. The production and use of corn (Misir üretimi ve kullanımı). Kocaoluk Yayınevi, Istanbul.

Kiziloglu, F.M., U. Sahin, Y. Kuslu, T. Tunc. 2009. Determining water-yield relationship, water use efficiency, crop and pan coefficients for silage maize in a semiarid region. Irrig. Sci 27: 129-137.

Kruse, S., A. Hermann, A. Kornher, F. Taube. 2008. Evaluation of genotype and environmental variation in fiber content of silage maize using a model-assisted approach. Eur. J. Agron. 28: 210-223.

Kumar, A., R.S. Jaiswal, M.L. Verma, Y.P. Joshi, 2001. Effect of nitrogen level and cutting management on yield and quality of different varieties of oat fodder. Indian Journal of Animal Nutrition. 18: 262-266.

Kusvuran, A., M. Kaplan, R.I. Nazl1, V. Saruhan, Y. Karadag. 2015. Determination of possibilities to grow some corn (Zea mays L.) cultivars for silage production under Middle Kizilirmak Basin ecological conditions. Journal of Agricultural Faculty of Gaziosmanpasa University, 32: 5767.

Lassey, K.R. 2007. Livestock methane emission: from the individual grazing animal through national inventories to the global methane cycle. Agr. Forest Meteorol. 142: 120-132.

Lopez, S., H.P.S. Makkar, C.R. Soliva. 2010. Screening plants and plant products for methane inhibitors. In "In vitro screening of plant resources for extra nutritional attributes in ruminants. Nuclear and related methodologies", Ed; Vercoe PE, Makkar HPS, Schlink A, London, New York, USA.

Mahajan, S., N. Tuteja. 2005. Cold, salinity and drought stresses. An overview. Arch. Biochem. Biophys. 444: 139-158.

McDonald, P., A.R. Henderson, S.J.E. Heron. 1991. The Biochemistry of Silage. Second Edition. p. 340, Chalcombe Publication.

Meeske, R., G. Ashbell, Z.G. Weinberg, T. Kipnis. 1993. Ensiling forage sorghum at two stages of maturity with the addition of lactic acid bacterial inoculants. Anim. Feed Sci. Technol. 43: $165-175$.

Menke, K.H., Raab, L., Salewski, A., Steingass, H., Fritz, D., Schneider, W. 1979. The estimation of the digestibility and metabolizable energy content of ruminant feedingstuffs from the gas production when they are incubated with rumen liquor in vitro. J. Agr. Sci. 93: 217-222.

Menke, K.H., Steingass, H. 1988. Estimation of the energetic feed value obtained from chemical analysis and in vitro gas production using rumen fluid. Anim. Res. Dev. 28: 7-55.

Mould, F.L., E.R. Ørskov, S.O. Mann. 1983. Associative effects of mixed feeds. I. Effects of type and level of supplementation and the influence of the rumen fluid $\mathrm{pH}$ on cellulolysis, in vivo and dry matter digestion of various roughages. Anim. Feed Sci. Technol. 10: 15-30.

Neylon, J.M., L. Kung. 2003. Effects of cutting height and maturity on the nutritive value of corn silage for lactating cows. J. Dairy Sci. 86: 2163-2169.

Otegui, M.E., F.H. Andrade, E.E. Suero. 1995. Growth, water use, and kernel abortion of maize subjected to drought at silking. Field Crop Res. 40: 87-94

Pelleschi, S., J.P. Rocher, J.L. Prioul. 1997. Effect of water restriction on carbohydrate metabolism and photosynthesis in mature maize leaves. Plant Cell Environ. 20: 493-503.

Ping, W.U., Q. Dai, Q. Tao. 1993. Effect of fertilizer rates on the growth, yield and kernel composition of sweet corn. Commun. Soil Sci. Plant Anal. 24: 237-253.

SAS, 1999. SAS User's Guide. Statistic. Statistical Analysis Systems Institute Inc., Cary, NC.

Setter, T.L., R. Parra. 2010. Relationship of carbohydrate and abscisic acid levels to kernel set in maize under postpollination water deficit. Crop Sci. 50: 980-988.

Sezer, I., S. Yanbeyi. 1997. The effects of plant density and nitrogen fertilization on corn yield, yield components and some plant characteristics of popcorn grown in the Carsamba Valley. Turkish Second Field Crop Congress, 22-25 September 1997, Samsun, pp 128-133 (in Turkish).

Sharp, R.E., W.J. Davies. 1979. Solute regulation and growth by roots and shoots of water-stressed plants. Planta. 147: 43-49.

Song, Y., C. Birch, S. Qu, J. Hanan. 2010. Maize canopy production under contrasted water regimes. Ann. Appl. Biol. 157: 111-123.

Spielbauer, G., L. Margl, L.C. Hannah, W. Romisch, C. Ettenhuber, A. Bacher, A. Gierl, W. Eisenreich, U. Genschel. 2006. Robustness of central carbohydrate metabolism in developing maize kernels. Phytochemistry. 67: 1460-1475.

Subedi K.D. B.L. Ma. 2005. Nitrogen uptake and partitioning in stay-green and leafy maize hybrids. Crop Sci. 45: 740-747. 
Swank, J.C., F.E. Below, R.J. Lamber, R.H. Hageman. 1982. Interaction of carbon and nitrogen metabolism in productivity of maize. Plant Physiol. 70: 185-190.

Tukel, T., R. Hatipoglu. 1997. "Grass Land Management", Cukurova University, Faculty of Agriculture, Text book Publication Number A-59, Adana, 152pp (in Turkish).

Tumer, S. 2001. Silo and Silage Techniques, Ministry of Agriculture, Food and Livestock, General Directorate of Organization and Support. Publication Department, Ankara (in Turkish).

Uribelarrea, M., F.E. Below, S.P. Moose. 2004. Grain composition and productivity of maize hybrids derived from the Illinois protein strains in response to variable nitrogen supply. Crop Sci. 44: 1593-1600.

Van Soest, P.J. 1963. The use of detergents in the analysis of fibre feeds. II. A rapid method for the determination of fibre and lignin. Journal of the Association of Official Analytical Chemists. 46: 829-835.
Van Soest, P.J., and R.H. Wine. 1967. The use of detergents in the analysis of fibrous feeds. IV. Determination of plant cell wall constituents. Journal of the Association of Official Analytical Chemists. 50: 50-55.

World Water Assessment Program, 2009. The United Nations World Water Development Report 3. Water in a Changing World. UNESCO, Paris, and Earthscan, London.

Yilmaz, M. 2005. The effects of nitrogen fertilization on yield and some agronomical traits of some corn (Zea mays L.) varieties grown as silage. MSc Thesis, Gaziosmanpasha University, Institute of Natural and Applied Sciences (in Turkish).

Yosef, E., A. Carmi, M. Nikbachat, A. Zenou, N. Umiel, J. Miron. 2009. Characteristics of tall versus short-type varieties of forage sorghum grown under two irrigation levels, for summer and subsequent fall harvests, and digestibility by sheep of their silages. Anim. Feed Sci. Technol. 152: 1-11. 